\title{
Implications of Co-Curricular Activities on Quality Education in Public Secondary Schools in Kenya
}

\author{
Nelson Siocha Omae, Henry Nyabuto Onderi and Benard Mwebi \\ honderi@jooust.ac.ke
}

\begin{abstract}
The purpose of the study was to explore implications of co-curricular activities on quality education in public secondary schools in Kisii County, Kenya. The objective of the study was to establish the impact of co-curricular activities on quality education. This study employed the Production Function Theory and adopted sequential explanatory design. Population of study consisted of 9 education officers, 334 principals and 334 senior teachers. Stratified sampling technique was used to select 181 principals and 181 senior teachers while saturated sampling was used to select nine education officers. Krescie and Morgan's formula was used to obtain the sample size. Instruments for data collection were two questionnaires, an interview schedule and a document analysis guide. Reliability was done by piloting in 34 schools through the split-half method. The reliability index for the instruments was 0.826 . The validity was done by expert judgment and by making them simple. The quantitative data was analyzed using descriptive and inferential statistics. The qualitative data was analyzed using thematic analysis. It was concluded that CCA facilities are inadequate, have not attained perfect utilization because of low emphasis, inadequate monitoring and supervision by teachers. This study will help all education stakeholders make decisions regarding implemention of policies that ensure provision of CCA for quality education. The researcher recommends that the Ministry of Education and schools revisit their policies related to the provision of CCA for quality education and work towards their implementation.
\end{abstract}

Key words: Co-curricular Activities, Quality of Education, Public Secondary Schools, Kisii County, Ministry of Education, Pre-primary, Primary and Higher Education levels

\section{INTRODUCTION}

UNICEF (2000) asserted that quality education includes learners who are healthy, wellnourished and ready to participate and learn, and supported in learning by their families and communities; school environments that are healthy, safe, protective and gender-sensitive, and provide adequate resources and facilities; content that is reflected in relevant curricula and materials for the acquisition of basic skills, especially in the areas of literacy, numeracy and skills for life, and knowledge in such areas as gender, health, nutrition, HIV/AIDS prevention and peace; processes through which trained teachers use child-centred teaching approaches in well-managed classrooms and schools and skilful assessment to facilitate learning and reduce disparities and outcomes that encompass knowledge, skills and attitudes, and are linked to national goals for education and positive participation in society.

Wasal and Mohammad (2014) carried out a study to explore the role of co-curricular activities in school effectiveness in schools in Khyber, Pakistan. Three separate questionnaires were used to gather data from principals, teachers and students. The questionnaire contained items and statements, which were structured around eliciting responses from principals, teachers and students about factors that contributed to school effectiveness. The interviews were based on 10 items/statements, which were held with 60 parents whose children were in 10 classes of 
the sampled schools. The data were analyzed both quantitatively and qualitatively. In order to be logical and scientific in approach, the analysis was further made meaningful with the application of statistical measures. The present study filled the gap by being conducted in Kisii County, Kenya, exploring the implications of co-curricular activities on quality of education in public secondary schools.

Israel, Maphosa and Beginner (2012) conducted a study that sought to establish educators' views on the influence of learners' participation in school co-curricular activities on their academic performance. The study adopted a case study design that utilized both quantitative and qualitative approaches. Data were solicited from educators in both private and public schools in one educational district in the Eastern Cape Province of South Africa. The study employed a semi-structured questionnaire to collect quantitative data and phenomenological interviewing to gather qualitative data. The present study filled the gap by using a questionnaire, an interview schedule and a document analysis as instruments of data collection exploring the implications of co-curricular activities on quality of education in public secondary schools. Quantitative data collected were coded and analyzed through a blend of both descriptive and inferential statistics. Qualitative data were analyzed using content analysis method.

Rahel (2012) carried out a study to find out factors in practice of co-curricular activities and how they build students' talent in Addis Ababa. Whereas the researcher used a Cross sectional study, in the present study sequential explanatory design was employed within mixed method approach. About 73\% of teachers of three schools responded that they did not get training on Co-curricular activities, but the Addis Ababa Education Bureau said even though it is irregular, some teachers took training. $27.9 \%$ and $26.7 \%$ of teachers and students, respectively, said there is very high shortage of facility, $85 \%$ of teachers explained that Woreda education office did not pay attention to Co-curricular activities. Addis Ababa Education Bureau and sub city Education offices mentioned 18-21 Co-curricular activities are expected in each preparatory school. Practice of co-curricular activities is affected by untrained teachers, shortage of materials, the presence of inactive clubs in school compounds, and unavailability of adequate budget for co-curricular activities.

UNESCO (2011) indicated that, in developing countries, the examination results are often used as a proxy for the quality of education. The report further revealed that an equally reliable measure of quality of education is whether learners are learning effectively, improving their knowledge, skills and abilities; widening their experience and growing socially and morally or not. Further, ability to work with others, readiness to accept responsibility and to work for public good are highly praised characteristics among indicators quality of education.

Abisaki, Mutsotso and Poipoi (2013) investigated Non-Formal Curricular Activities (NFCAS) in Mumias Sub-County. In order to achieve the set objectives, the researcher sought to establish the NFCAS that are available in secondary schools and the NFCAS that were popular, the adequacy of the facilities that promote NFCAS and the frequency of participation of students in NFCAS. Whereas the study employed descriptive survey design, the present study filled the knowledge gap by employing a sequential explanatory design that involves the use of both quantitative and qualitative approaches. Random sampling was undertaken to identify the school types, while purposive sampling was used to select the respondents that were information rich. The NFCAs available included a variety of games and sports, clubs and societies and performing arts; Football, Netball and Volleyball were most popular games 
whereas basketball was the least popular. The study concluded that student's access to and participation in non-formal curriculum activities is limited because of lack of adequate facilities and unavailability of time. The recommendations of the study were that the scope of the activities be broadened to involve whole school populations and that schools strengthen their support of the activities. In conclusion, the Ministry should ensure that guidelines on registration of schools based on availability of space be adhered to.

GoK (2014) and GoK (2015) support the policy framework on reforming Education and Training Sector in Kenya to realign it to vision 2030 and the constitution of 2010. The Sessional papers noted that quality education entails relevance of curriculum; adequacy; knowledge; skills and competencies; globally competitive education; acquisition of desired values, attitudes, innovativeness and creativity. Further, it asserted that quality education is that which enables people develop all their attributes and skills to achieve their potential as human beings and member of societies. Quality education enables each of us develop all our talents to the full and to realize our creative potential including responsibility for our lives and achievement of personal aims.

GoK (2012) noted that National goals for education and outcome statements that translate those goals into measurable objectives should provide the starting point for the development and implementation of curriculum and co-curricular activities.

UNICEF (2005) documents state that school curriculum has three dimensions - formal, nonformal and informal - which are prerequisites for a holistic approach towards learning and in turn well-balanced development of learners. The report indicates that quality education aims at the wholesome development of children. In fact, all-round development is the key theme of education. Additionally, when a child comes to school, he/she comes in totality and so education should help him/her develop total personality.

Several studies in Africa and Kenya (World Bank, 2009; Bray, Clarke \& Stephens 2002; Ministry of Education, Kisii County, statistics office 2014) have largely focused on the K.C.S.E. mean score, student teacher ratio, availability of educational facilities as the only parameters of quality education in secondary institutions of learning. The present study dealt with implications of co-curricular activities on quality education.

Previous studies (Davalos, Shavez \& Guardiola 1999; Sitra 2005; Green 1988) reveal that students' involvement in co-curricular activities make them likely to stay in school and improve retention rates. A Report on The Condition of Education, United States Department of Education, National Centre of Education Statistics (1995) found that participation in CCAs might affect opportunities for students to learn the values of teamwork, a channel for reinforcing skills and the opportunity to apply academic skills in arenas as a part of a wellrounded education. According to Education Week, Washington (2001), new data from the U.S.A. show that participating in curriculum activities link to better performance in school. A study done by Davalos, Shavez and Guardiola (1999) showed the effect of co-curricular activities in students' dropout rates in school for Mexican-American youths. These results support the argument that extracurricular activity involvement may provide individuals with a sense of belonging that may contribute to higher retention rates for these individuals.

Green (1988) focused on competency building through co-curricular activities. Sitra (2005) focused on teachers' perception on the effectiveness of co-curricular activities of Malaysian school but nothing is mentioned on its implication on quality education. According to the 
Kenya Institute of Education (K.I.E.) strategic plan 2006-2010 (2007), there is an issue that has remained unresolved on the mode of curriculum development process, which is the fact that within the Kenyan education system there is an examination culture that is so entrenched in the system, such that the emphasis on academic performance with little emphasis on other aspects of the curriculum is so great. K.I.E. admits that the need to strengthen co-curricular activities should not be underestimated. The study revealed that lack of involvement in the cocurricular activities produces a negative effect on the academic performance of the students. Academic performance is a parameter of quality education and the two are directly proportional. Though studies have been done on co-curricular activities, none of these studies has focused on implications of co-curricular activities on quality education

A report by Kisii County Education Conference (2011), which brought together scholars, parents, professionals, political leaders and other players, held at Kisii University Grounds, indicated that there is need for research on the cause of dwindling quality education in Kisii County. It further noted that our students are not learning despite the impressive enrolment rates in the County and only further research can help establish the problem. It is against this scenario that the study intended to explore selected predictors of quality education and their implications on public secondary schools in Kisii County.

\section{STATEMENT OF THE PROBLEM}

The quest to achieve Education for All (EFA) is fundamentally about ensuring that students' gain of the knowledge and skills they need to better their lives and to play a role in building more peaceful and equitable societies. As many societies strive to universalize basic education, they face the momentous challenge of providing conditions where genuine learning can take place for each learner for quality education. This is why focusing on quality education is an imperative for achieving EFA. During the past decade, much has been done globally to provide quality basic education for children, an obligation for the Convention on the Rights of the Child. In Kenya, the Directorate of Quality Assurance and Standards (DQA\&S) department in the Ministry of Education (MoE) is charged with the responsibility of ensuring quality. Statistical reports from MoE on Kisii County assert that, despite the fact that major strides have been made to provide quality education through Free Secondary Education (FSE) policy, the policy seems not to be successful going by the current indicators of exhibit of low quality education. This is evidenced by Kenya's system of education: specifically, Kisii County is being dominated by examination-oriented teaching giving little emphasis on co-curricular activities. This scenario has raised concern because it means that the resources devoted to education are being wasted, and this may jeopardize the future of the education system in Kenya as a whole and in Kisii County, in particular. While some studies done in Kisii have attempted to address the issue, they did not isolate or explore on the implications of CCA on quality education in public secondary schools in Kisii County, Kenya. Therefore, it is against this worrying trend that prompted the researcher to undertake a study on implications of CCA on quality education in public secondary schools in Kisii County, Kenya.

\section{Objective of the study}

The following was the objective of the study:

To find out implications of Co-curricular activities on quality education in public secondary schools. 


\section{Research design}

\section{RESEARCH METHODOLOGY}

This study adopted a mixed method research approach. The sequential explanatory design was employed within mixed methods approach. Its purpose is to use qualitative results to assist in explaining and interpreting the findings of quantitative study.

\section{Sampling procedures and sample size}

The County had 334 public secondary schools against 334 principals and 344 senior teachers. Simple random sampling was used to select schools, which were sampled in each category. The lottery technique was applied where a symbol YES was placed on 181 out of 334 public secondary schools. Small pieces of paper (of equal size, colour and texture) folded into equal size and shape, were placed in a container, mixed well and then each principal was allowed to pick one piece of paper at a time in their respective categories. In this case, the schools of the 181 principals who picked a yes were automatically included in the sample.

One hundred and eighty-one public secondary schools were sampled for the study. One hundred and eighty-one principals and 181 senior teachers were used in the study, a representation of 53.6\% as justified by Fisher et al. cited in Mugenda and Mugenda, (2013). Saturated random sampling was used to select nine education officers. Stratified random sampling was used to select schools for the pilot study. Krescie and Morgan's formula shown below was used to obtain the sample size for the research study.

\section{Research instruments}

This research used questionnaires and interview schedule for Sub-county education officers, principals, and senior teachers to collect primary data for the study. A document analysis schedule was used to collect data that are not directly obtainable with other research instruments

\section{Questionnaires}

Questionnaires developed by the researcher were used to collect data from principals and senior teachers. Data were collected using two questionnaires. Each questionnaire was divided into part A and B. Part A of each questionnaire had four items based on background information of the respondents. Part B of the questionnaire had test items based on the four objectives of the study. Each questionnaire had close-ended test items measured on a 5-point Likert scale. For questions with a positive stem, Strongly Agree (SA) scored highest (5), while Strongly Disagree (SD) scored lowest (1). For questions with a negative stem, Strongly Disagree (SD) scored highest (5), while Strongly Agree (SA) scored lowest (1).

\section{Interview schedule}

The researcher administered a structured interview schedule to education officers, which contained open-ended questions based on the research objectives. An in-depth interview was deemed ideal for investigating where researchers were seeking individual interpretations and responses.

\section{Document analysis schedule}

The researcher examined secondary school stores records to check on availability of school CCA equipment. The information obtained was discussed with the principals with the aim of collecting data. 


\section{Validity of the instruments}

To ensure construct validity, short and straightforward close-ended questions were used. The questionnaire was made simpler and easier to understand by using short and simple sentences. They were arranged from simple to complex. They allowed the respondent to approximate the exact response as close as possible. In addition, a detailed verbal descriptions and clear instructions were provided during the group administration, which the researcher conducted personally. To ensure validity of the questionnaire, expert judgment of lecturers of the university was sought and recommendations incorporated in questionnaire.

\section{Reliability of instruments}

The split-half method was used to ascertain the reliability of the questionnaires, using the Split-Half reliability by Spearman Brown Formula:

An SPSS output indicates a correlation coefficient $(r=0.826)$ greater than 0.6.

\section{Data collection procedures}

Permission to conduct the research was sought through the Director, Board of Post graduate studies, Jaramogi Oginga Odinga University of science and technology. Before data collection was conducted, a research permit was sought from the National Commission of Science Technology and innovation (NACOSTI). Permission was further sought from the County Director of Education. Subsequently, an introductory letter from the county education office was sought. The principals of the sampled schools to be included in the study were then consulted in advance to obtain consent. Two sets of questionnaires and document analysis were administered to the principals, senior teachers whereas interview schedule was administered to sub-county education officers by the researcher. In order to ensure a high level of response, the researcher visited the individual secondary schools and, in all cases, the instruments were administered by the researcher personally. The researcher explained how to fill in the questionnaires and document analysis to the respondents. A period of two weeks was given in which to fill in the questionnaires and document analysis after which the researcher collected them. The purpose of administering the questionnaires and document analysis for two weeks was to give the respondents enough time to go through them and clearly understand the items to give the most accurate answers. They were sorted out to see if there were complete ones. The instruments were then organized and scored ready for analysis. The respondents were assured of the confidentiality of their responses. At the same time, the researcher conducted an audio taped, face-to-face interview to the education officers in their offices at different dates each lasting one hour. After the field, the data were taken for analysis.

\section{Data analysis}

The quantitative data collected were analysed with the aid of the Statistical Package for Social Sciences while the qualitative data collected were analysed using thematic analysis.

\section{Quantitative data analysis}

Quantitative data collected were first edited and checked for completeness. During coding, the questionnaire for the principals was assigned $P$ whereas that for senior teachers was assigned $\mathrm{S}$. For section A of the questionnaire, question 1 on gender male was coded 0 and female coded 1. Those who did not specify their gender were coded 9, labelled unknown and the same code was used for those who ticked both male and female or had a missing specification. Question 2, on the level of education, diploma was coded 1, bachelor was coded 2, master was coded 3 and others were coded 9. Question 3, year of experience, below 4 years was coded 1, between 4-6 years was coded 2, 7-9 was coded 3 and 9 years and above was coded 4 . The missing age was 
coded 999. Finally, on the staffing of schools, understaffed was coded 1, balanced was coded 2, and overstaffed was coded 3. The missing staffing was coded 999. For section B of this questionnaire, the responses to all the questions strongly agree were coded 5 , agree was coded 4 , neutral was coded 3 , disagree was coded 2 and strongly disagree was coded 1 . The Objective consisted of one part which had a set of Likert scaled 10 test items that sought to investigate their views on CCA and its implications on quality of education in public secondary schools. The questionnaire was administered to principals and senior teachers whose responses were computed as percentages and reflected. Their responses were computed as percentage frequencies. To establish whether there was any significant relationship between CCA and quality of education in public secondary schools, the research computed Pearson's ProductMoment Coefficient of correlation between the scores of the two variables. The results of the analysis were shown in descriptive statistics and correlation results.

\section{Qualitative data analysis}

Data from interview schedule was analyzed using the thematic framework and the following steps were considered; this research followed the principles of thematic analysis

\section{Descriptive analysis of the Study}

FINDINGS, INTERPRETATION AND DISCUSSION

Table 1: Relationship of Co-Curricular Activity Parameters and Quality of Education $(n=151,136)$

\begin{tabular}{|c|c|c|c|c|c|c|c|c|c|c|}
\hline ITEM & & Fre & ncy & & & & & & & \\
\hline & $\mathrm{R}$ & 1 & 2 & 3 & 4 & 5 & $\mathrm{TF}$ & $\mathrm{TS}$ & AV & $\% \mathrm{SCORE}$ \\
\hline Students & $\mathrm{ST}$ & 10 & 24 & 15 & 73 & 29 & 151 & 540 & 2.57 & 51.52 \\
\hline $\begin{array}{l}\text { participate in } \\
\text { football daily }\end{array}$ & $\mathrm{P}$ & 15 & 44 & 15 & 43 & 19 & 136 & 415 & 2.05 & 51.02 \\
\hline $\begin{array}{l}\text { Students } \\
\text { participate in }\end{array}$ & $\mathrm{ST}$ & 19 & 9 & 10 & 79 & 34 & 151 & 553 & 2.66 & 53.24 \\
\hline $\begin{array}{l}\text { students council } \\
\text { on daily basis }\end{array}$ & $\mathrm{P}$ & 45 & 24 & 17 & 23 & 27 & 136 & 371 & 2.72 & 54.55 \\
\hline $\begin{array}{l}\text { Students } \\
\text { participate in }\end{array}$ & ST & 23 & 37 & 19 & 39 & 33 & 151 & 475 & 4.14 & 62.91 \\
\hline $\begin{array}{l}\text { social events on } \\
\text { daily basis }\end{array}$ & $\mathrm{P}$ & 24 & 18 & 15 & 36 & 43 & 136 & 464 & 4.41 & 68.23 \\
\hline Students & $\mathrm{ST}$ & 8 & 10 & 15 & 61 & 56 & 150 & 597 & 4.08 & 79.60 \\
\hline $\begin{array}{l}\text { participate in clubs } \\
\text { on weekly basis }\end{array}$ & $\mathrm{P}$ & 15 & 8 & 0 & 74 & 39 & 136 & 522 & 3.83 & 76.76 \\
\hline $\begin{array}{l}\text { Students } \\
\text { participate in }\end{array}$ & $\mathrm{ST}$ & 18 & 13 & 22 & 55 & 43 & 151 & 545 & 4.60 & 72.18 \\
\hline $\begin{array}{l}\text { school publication } \\
\text { regularly }\end{array}$ & $\mathrm{P}$ & 28 & 15 & 13 & 35 & 38 & 129 & 427 & 3.31 & 66.20 \\
\hline $\begin{array}{l}\text { Inadequate } \\
\text { playgrounds hinder } \\
\text { many students }\end{array}$ & ST & 23 & 19 & 12 & 60 & 37 & 151 & 522 & 2.45 & 69.13 \\
\hline $\begin{array}{l}\text { from being } \\
\text { involved in co- } \\
\text { curricular activities }\end{array}$ & $\mathrm{P}$ & 8 & 18 & 27 & 43 & 55 & 151 & 572 & 2.78 & 75.76 \\
\hline Some of the & ST & 15 & 14 & 14 & 76 & 32 & 151 & 549 & 1.63 & 72.71 \\
\hline
\end{tabular}


existing facilities

are obsolete thus

discouraging

$\begin{array}{lllllll}P & 26 & 23 & 14 & 30 & 43 & 136\end{array}$

449

$1.30 \quad 66.02$

students from

utilization

Students

participate

in ST 29

$\begin{array}{lll}18 & 10 & 68\end{array}$

$26 \quad 151$

497

$2.29 \quad 65.82$

volley ball on daily

basis

$\begin{array}{lllll}\mathrm{P} & 23 & 18 & 19 & 55\end{array}$

Students

$\begin{array}{lllll}\text { ST } & 25 & 23 & 9 & 74\end{array}$

$20 \quad 135$

436

$2.22 \quad 64.59$

participate in net

ball on daily basis

P 35

$31 \quad 15$

$20 \quad 151$

494

$2.27 \quad 57.05$

Students

participate

$$
\text { ST } 9
$$

194

$29 \quad 26$

136

388

$3.85 \quad 65.43$

in

$\begin{array}{lllll}\text { athletics on daily } \mathrm{P} & 17 & 13 & 33\end{array}$

$79 \quad 40$

151

575

$4.80 \quad 76.15$

basis

Students

$\begin{array}{llllllllll}\mathrm{ST} & 34 & 44 & 3 & 54 & 16 & 151 & 427 & 2.82 & 56.55\end{array}$

22

51

136

485

$4.56 \quad 71.32$

participate in

indoor games on

daily basis

Co-curricular

facilities are

$$
\text { ST } 43 \quad 46 \quad 14
$$

29

$19 \quad 151$

388

$2.56 \quad 51.39$

sufficient

to

facilitate proper

development of co-

$\begin{array}{llll}P & 23 & 18 & 17\end{array}$

27

$45 \quad 130$

443

$2.40 \quad 68.15$

curricular talents

among the students

Students

$\begin{array}{lrllllllllll}\text { participate } & \text { in } & \text { ST } & 30 & 34 & 21 & 44 & 22 & 151 & 447 & 2.96 & 59.20 \\ \text { hockey on } & \text { daily } & \text { P } & 15 & 18 & 13 & 60 & 36 & 142 & 510 & 2.59 & 61.83\end{array}$

basis

$\begin{array}{llll}\mathrm{P} & 15 & 18 & 13\end{array}$

$142 \quad 510$

$2.59 \quad 61.83$

co-curricular

programs of school

ST $\quad 15 \quad 10 \quad 11 \quad 72$

$43 \quad 151$

571

$3.78 \quad 75.62$

promote

sustainable

commitment

to

P 39

713

158

$136 \quad 290$

$2.13 \quad 42.64$

educational

outcomes

CCA

$\begin{array}{llll}\text { ST } & 21 & 13 & 3\end{array}$

$79 \quad 35$

151

547

$2.62 \quad 72.45$

teachers/Patrons

are regularly,

$\begin{array}{lllllllllll}\text { (twice or more a } & \mathrm{P} & 23 & 35 & 28 & 19 & 31 & 136 & 408 & 2.00 & 60.00\end{array}$

year) trained on

their roles in CCA

Students

participate

$$
\text { in }
$$

in $\mathrm{ST}$

$\begin{array}{llllllllll}\mathrm{ST} & 80 & 51 & 6 & 5 & 8 & 150 & 260 & 1.73 & 34.66\end{array}$


Omae, N. S., Onderi, H. N., \& Mwebi, B. (2017). Implicatons of Co-Curricular Activities on Quality Educatoin in Public Secondary Schools in Kenya. Advances in Social Sciences Research Journal, 4(1) 106-120.

\begin{tabular}{|c|c|c|c|c|c|c|c|c|c|c|}
\hline $\begin{array}{l}\text { handball on daily } \\
\text { basis }\end{array}$ & $\mathrm{P}$ & 80 & 51 & 6 & 5 & 8 & 150 & 260 & 1.73 & 34.66 \\
\hline $\begin{array}{l}\text { Participation } \\
\text { and/or }\end{array}$ & ST & 33 & 51 & 17 & 22 & 13 & 136 & 339 & 2.49 & 49.85 \\
\hline $\begin{array}{l}\text { achievement done } \\
\text { in all in CCA }\end{array}$ & $\mathrm{P}$ & 33 & 51 & 17 & 22 & 13 & 136 & 339 & 2.49 & 49.85 \\
\hline Mean of means & & 49.26 & 49.37 & 25.95 & 85.58 & 60.89 & 270.26 & 869 & 2.89 & 64.95 \\
\hline
\end{tabular}

Legend: Strongly Agree (5), Agree (4), Neutral (3), Disagree (2) and Strongly Disagree (1), Pprincipals, ST-senior teachers R-respondents

It was established from the Senior Teachers that students rarely participate in football on daily basis, as confirmed by majority 102 (67.5\%) of Senior Teachers. From the principals' point of view, the findings of the study show that co-curricular activities have substantial influence on quality of education. For instance, $62(45.6 \%)$ of principals truly agreed that students rarely participate in football on daily basis. It emerged from the findings of the study that although many [50 (39.7\%)] of senior teachers who were sampled for the study held a contrary opinion, a majority of $113(74.7 \%)$ of senior teachers were in disagreement that students participate in students council on daily basis.

Almost half $72(47.4 \%)$ of principals held the opinion that students participate in students' council on daily basis, $62(41.1 \%)$ others held a different opinion. These findings do not corroborate well with the assertion that students participate in social events on daily basis as indicated by $69(50.7 \%)$ of principals. Further, although $41(30.1 \%)$ of principals who took part in survey rejected the assertion that students participate in social events on daily basis, a majority of 75 (55.1\%) of senior teachers were in disagreement that students participate in clubs on daily basis, and thus few students are involved in co-curricular activities. However, it was revealed by the study findings that students rarely participate in clubs on daily basis, as revealed by $113(83.1 \%)$ of principals who took part in the survey. Similarly, whereas 66 $(44.7 \%)$ of senior teachers held an opinion that students participate in school publication on daily basis, 64 (42.4\%) refuted such claim. Coupled with that, is the issue that most students rarely participate in school publication on daily basis as noted by $73(52.7 \%)$ of principals, has a substantial influence on quality of education. The findings of the study indicated that an overwhelming majority of 131 (86.8\%) of senior teachers who took part in the survey confirmed that inadequate playgrounds hinder many students from being involved in cocurricular activities in most of the secondary schools in Kisii County. The study noted that more than half $[73(53.7 \%)]$ of principals who took part in the study alluded that inadequate playgrounds hinder many students from being involved in co-curricular activities, but another group [85 (62.5\%)] of principals insisted that some of the existing facilities are obsolete thus discouraging students from utilization.

It was held by most senior teachers who took part in the survey that some of the existing facilities are obsolete thus discouraging students from utilization [98 (74.9\%)]; that students rarely participate in school publication on a daily basis [97 (64.2\%)]; and that students rarely participate in volleyball on a daily basis as a school policy [108 (71.5\%)] as held by the principals. The findings of the study show that more than four out of every five [113 (83.1\%)] principals who took part in the survey disagreed that students participate in netball on daily basis. On the contrary, although $70(46.4 \%)$ of senior teachers agreed that students participate 
in netball on daily basis, a significant majority [78 (51.7\%)] of senior teachers held the perception that students do not participate actively in co-curricular activities.

On the students' participation in co-curricular activities, it was clearly established that students rarely participate in indoor activities on daily basis. This was confirmed by more than three quarters 119 (78.8\%) of senior teachers who took part in the study. On the flip flop, the study shows that students rarely participate in indoor activities on daily basis in many of the secondary schools in Kisii County, as indicated by 112 (74.3\%) of principals.

The findings of the study show that many senior teachers [94 (62.2\%)] disagreed that students participate in athletics on daily basis. It was established that students participate in athletics on daily basis, as revealed by about three quarters [115 (76.2\%)] of senior teachers, about a similar proportion $(115 ; 75.5 \%)$ held the perception that CCA teachers/patrons are regularly (twice or more times a year) trained on their roles in CCA. On the same note, the findings of the study show that $98(73.5 \%)$ of principals who took part in the survey observed that cocurricular facilities are insufficient to facilitate proper development of co-curricular talents among the students; $65(47.8 \%)$ of them strongly agreed that students participate in cocurricular activities actively; 43 (31.6\%) of them also confirmed that schools take into consideration co-curricular activities in the academic annual plan of the school. Students rarely participate in handball on daily basis. This was confirmed by more than three quarters 131 (86.8\%) of the senior teachers who took part in the study. Unlike senior teachers, it was established that a significant majority [101 (74.2\%) of principals who took part in the study held a strong belief that students rarely participate in handball on daily basis in school.

\section{Coefficients of the co-curricular activities variable}

The largest Beta coefficient was .583, which was for sports implying it made the strongest unique contribution to explaining the dependent variable; the second largest Beta coefficient was .280, which was for Student council, implying it made the second strongest unique contribution to explaining the dependent variable, when the variance explained by all other variables in the model was controlled for. This was followed closely by the school publications with a Beta value of .278. The Beta value for clubs and debate were the lowest with 0.87 and .086, respectively, indicating that they both made the least contribution to the model. Further, it was discovered that of parameters; sports, school publications, student council, and social events made a statistically significant $(\mathrm{P}-\mathrm{value}<0.05)$ difference to the model.

\section{The regression model for the Co-Curricular Activities}

A regression model for the relationship between the Co-curricular activities variable and the parameters is shown below.

$\mathrm{Y}=0.09+3.081 \mathrm{x} 1+1.174 \mathrm{x} 2+\mathrm{x} 3+\mathrm{x} 4+\mathrm{x} 5+\mathrm{x} 6 \varepsilon$
Where:
$\mathrm{Y} \quad$ Co-Curricular Activities

$\mathrm{x} 1$ Sports, $\mathrm{x} 2$ Clubs, $\mathrm{x} 3$ Debate, $\mathrm{x} 4$ School publications, $\mathrm{x} 5$ Student council, $\mathrm{x} 6$ Social events It can be deduced from the above equation that co-curricular activities parameters that contributed to quality education in Kisii County in order of importance as were factored in the model as indicated above are the following: The parameter sports had a highest input of $\mathrm{R}=$ 3.081 towards co-curricular activities; it was followed by school publications which had an input of $\mathrm{R}=2.368$ units. Debate had the lowest input of $\mathrm{R}=.470$ units, whereas students council, social events, and clubs had $\mathrm{R}$ values of $2.455,2.346$, and 1.174 , respectively. 
The model is $23.2 \%$ explained by the parameters. That is, other factors (not covered in this regression model) could account for about $76.8 \%$ of the model. This means that there is a moderate relationship between co-curricular activities variable and quality education.

\section{DISCUSSION}

The administration is responsible for all CCAs held in the schools or on school grounds. When it appears to be beneficial or to conduct school activities, the board may authorize such activities to be conducted under such regulations as the administration deems necessary. Time allocated for CCA in most schools is misappropriated by giving preference to academic activities. In some schools such timetable affected only Form 3 and Form 4 but in other schools it was adopted by the whole school. The study noted that most CCAs were effectively implemented in schools in terms of allocating resources like rooms, furniture, fields, balls and other equipment. The study also found out that where training of patrons and students leaders was done, this positively affected the implementation of CCA in schools. In some schools CCA leaders and teachers were not regularly trained on their roles in the CCA activities. The teachers and students leaders felt they needed more training on CCA activities.

The study also indicates that monitoring and evaluation of co-curricular activities in the implementation of co-curricular activities in the schools was inadequate. Recognition and rewarding of participation and achievements was not done in majority of the schools. For example students are encouraged to participate more whenever they were recognized or rewarded. Teachers and students perception regarding the value of co-curricular activities affected the implementation of co-curricular activities. Participation in CCA encourages students to be given leadership position in the school. The issues and challenges in the implementation of CCA activities for example time management for students could be overcome if the students were given more guidance on how to balance academic activities and CCA activities. Participation in CCA encourages group participation, teamwork, co- operation and unity and also helped students to developed self-discipline by discouraging any deviant behavior.

Effective implementation of CCA should be put in place in every secondary school in Kenya. In a guiding manual for inspection by Government of Kenya (2000) areas to be inspected include finding out the variety of CCA, students' involvement programs, facility and equipment procurement, level of participation and system of rewarding performance. However, though the guideline says that the activities may not be rigidly divided up into periods of prescribed length as with a timetable, the Ministry does not give guidelines on how they should be implemented. In fact, there is a gap on the policy guideline on the management of the programmes. For example, several questions are left unanswered for example, should the school have yearly programmes for CCAs? How should the CCA be grouped for example, groups like: - Sports and games, uniformed (e.g. scouts, girl guides) and performing arts (Music and Drama), Club and societies. Should there be a grading system for participating students, to be reflected in a kind of certificate? The government therefore should give more specific guidelines on how CCA should be implemented and not just on how they should be inspected.

Sitra and Sasidhar (2005) on their study of teachers' perception on the effectiveness of cocurricular activities of Malaysian Schools, they concluded that students' involvement in cocurricular activities enhances their competencies in communication, cognitive, sell managing and academic. Sitra, further highlighted that significance steps must be taken to assure that every student participates actively in co-curricular activities, which are headed by teachers 
who are knowledgeable about their particular activity. However, most of the public schools do have physical instructor, irrespective of whether these are in possession of physical infrastructure/sports grounds or otherwise. This situation where there is no specific teacher in-charge of a CCA becomes a challenge in the implementation process of the activities because of lack of supervision from a teacher.

Mwisukha, Njororai and Onywera (2003) who documents that co-curricular program offer activities of interest to all students in the school. Students are encouraged to participate fully in the athletic, artistic, social and cultural life of the school. Involvement in the school's cocurricular program enables students to make new friends and develop talents and interests outside of the regular school curriculum. Further, they indicate that rote learning technique in Kenya produces individuals who cannot 'think outside the box'; this is because teaching and instructional material is provided in line with curriculum requirement. Reinforcing the rote learning technique is the failure by the education system to provide adequate co-curriculum activities that are vital for mental, physical and the development of talents in pupils and students (Ikagami, 2000 \& Mutuma, 2005).

GoK (2012) noted government and regulatory authorities must ensure that the schools do have the appropriate infrastructure for sports and other co-curricular activities before they are issued with the permission to run their classes. The infrastructure includes provision of rooms, fields, furniture's, balls, nets among others. All these resources require financial provision. As pointed earlier, one of the greatest challenges in the implementation of CCA in Kenya which also creates a gap in the entire education system is the fact that within the Kenyan education system, there is an over emphasis on the examination culture. This means that the culture is so entrenched in the system, such that, the emphasis on academic performance with little emphasis on other aspects of the curriculum is so great. Such issues as the moral, social, psychological, physical and social spiritual development need to be addressed if the learner is to experience holistic development. Mwisukha, Njororai and Onywera, (2003) noted that one of the major factors, affecting the operation of a successful development of co-curricular talents among the students is the provision of adequate facilities, equipment, and supplies. In general, the term facilities, equipment and supplies are used as an alternative word for each other. But in the field of physical education, games \& sports and in practical subject these three words have different meanings. In this regard, 'facilities' may be defined as an area, space or teaching station, it may be located either rout-of-doors or inside a building, such as classroom, play field, laboratory, gymnasium, auditorium.

\section{Summary}

\section{SUMMARY, CONCLUSIONS AND RECOMMENDATIONS}

The inferential analysis from the regression model equation indicate that co-curricular activities parameter, sports had a highest contribution of $\mathrm{R}=3.081$ towards co-curricular activities; it was followed by school publications which had an input of $\mathrm{R}=2.368$ units. Debate had the lowest input of $\mathrm{R}=.470$ units whereas students council, social events, and clubs had $\mathrm{R}$ values of $2.455,2.346$, and 1.174 respectively.

The descriptive analysis results of the study established from the respondents that short time allocated on daily basis for co-curricular activities enhances inefficient students' participation, as confirmed by majority of the respondents. 
It emerged from the findings of the study that although half of the respondents who were sampled for the study held a contrary opinion, a majority of them were in agreement that schools allocate a particular amount of money for co-curricular activities. Almost half of them held the opinion that lack of enough funds leads to late delivery of essential facilities for cocurricular activities, others held a different opinion. Similarly, whereas many of the respondents held an opinion that administration has positive attitude towards CCA. The findings of the study indicated that that an overwhelming majority of the respondents who took part in the survey confirmed that inadequate playgrounds hinder many students from being involved in co-curricular activities in most of the secondary schools in Kisii County. It was held by most of the respondents who took part in the survey that some of the existing facilities are obsolete thus discouraging students from utilization that there is little education on facilities that students can use to develop their talents and that school managers implement what has been deliberated as school policy. On the contrary, although almost half of the respondents were in agreement that students participate actively in co-curricular activities, a significant majority of them held the perception that students do not participate actively in cocurricular activities.

On the students' participation in co-curricular activities, it was clearly established that students are not given enough time and opportunity to take part in co-curricular activities. This was confirmed by more than three quarters of the respondents who took part in the study. On the flip flop, the study show that co-curricular facilities are insufficient to facilitate proper development of co-curricular talents among the students in many of the secondary schools in Kisii County, as indicated by majority of respondents.

The findings show that many respondents agree that schools take into consideration cocurricular activities in the academic annual plan of the school. It was established that curricular and co-curricular programs of school promote sustainable commitment to educational outcome, as revealed by about three quarters of the senior teachers, about a similar proportion of them held a perception that CCA teachers/Patrons are regularly, (twice or more a year) trained on their roles in CCA. Participation and/or achievement in CCA is irregularly, (termly/yearly) recognized and/or rewarded in school.

\section{Conclusion}

Based on the findings of the study the following conclusions were made:

The parameter, sports had a highest input; coefficient of determination value towards cocurricular activities; it was followed by school publications. This implies that sporting activities need to be emphasized in schools as they contribute immensely to quality education provision. The parameter, debate had the lowest contribution whereas students' council, social events and clubs had their input values declining respectively. The model is $23.2 \%$ explained by the parameters. This means that there is moderate relationship between co-curricular activities variable and quality education.

\section{Recommendations}

In light of the findings about implications of co-curricular activities on quality education the study recommends that:

More awareness campaigns need be carried out to ensure that education officers, administration, teachers, parents and teachers in are on the vital role co-curricular activities play in talent development. A clear programme should be prepared on when and how cocurricular activities should be offered in schools. Time allocated to each activity should also be specified. Proper Supervision of co-curricular policy implementation in schools should be 
instituted so as to ensure that all activities are offered to students as per the ministry policy. Co-curricular activities should be adequately funded to ensure that all students have an opportunity to participate. The curriculum for teacher training should include professionalism in co-curricular activities; Parents should be sensitized in identifying, nurturing and developing their children's co-curricular talents; school administration should identify talented and gifted children be offered regularly in the school. Students should be made aware of the importance of balancing their studies and CCA activities as well as be taught principles of time management so as to balance time for CCA and academic activities. Teacher patrons and CCA leaders should be regularly (termly/yearly) trained on the entire process of CCA implementation in order for them to carry out their duties effectively. Schools should have inter-class competition while the school administration should support CCA activities financially for effective implementation of CCA in their schools. A grading system for CCA participation and achievement should be adopted to encourage continuous participation for four years in secondary schools. Lastly it is recommended that school administration should avail adequate playgrounds, equipment and giving CCA members support.

\section{Suggestions for further research}

This study focused on CCA and its implications on quality education provision. It is imperative to conduct similar study covering on implications of CCA on quality education in private secondary schools in Kenya. This will broaden and give comparison with the current study.

\section{References}

Abisaki, O. Mutsotso, S. Poipoi, M (2013). Analysis of Non-Formal Curricular Activities in Mumias Sub-County, Kenya. International Journal of Academic Research in Business and Social Sciences September, Vol. 3, No. 9 ISSN: 2222-6990. Kibabii University College Kibabii University College. 595 www.hrmars.com/journals

Daralos, B.D. Ernest, LC. and Robert, JG(1999). The effects of extracurricular activity, ethnic identification and perception of school student dropout rates. Hispanic Journal Behaviour Sciences.

GoK (2005) Kenya Education Sector Support Programme (KESSP) (2005-2010). Ministry of Education. Kenya Nairobi.

GoK (2007). Secondary Education Strategy. Nairobi: Ministry of Education.

GoK (2012). Sessional Paper No.14 of 2012 on realigning education and training to the Constitution of Kenya 2010 and Vision 2030 and beyond. Ministry of Education Science and Technology. Nairobi. Kenya.

GoK (2014). Sessional Paper number. A policy framework for education Training and Research; Meeting the Challenges of Education Training and Research in Kenya. Nairobi: Government Printer.

GoK (2015). Quality assurance and standards office http: //www.kisii.go.ke/index. php/socioeconomics/item/1650-tsc-kisii-county-branch

Green, M (1988). Wellbeing and Retention: A Senior Secondary Student Perspective. The Australian Educational Researcher, 36(2), 119-145.

Ikagami, H. (2000) Character and Personality changes in the Athletes. In G.N. Kenyan (Ed.) Contemporary Psychology of sports. Chicago: athletic institute.

Israel, T. Maphosa, W. and Beginner, M (2012). The Influence of Learners' Participation in School Co-curricular Activities on Academic Performance: Assessment of Educators' Perceptions; University, Department of Education and South Africa University of Venda, Centre for Higher Education Teaching and Learning, South.

Mwisukha, Njororai and Onywera, (2003). The student development task and lifestyle inventory: An approach to measuring students psycho sociological development. Journal of College Student Development, 31, 108-120.

Rahel G (2012) Factors in Practice of Co- curricular Activities and how they Build Students' Talent. Addis Ababa University School of Graduate Studies; Institute of Educational Research Practice of Co- curricular Activities and 
Omae, N. S., Onderi, H. N., \& Mwebi, B. (2017). Implicatons of Co-Curricular Activities on Quality Educatoin in Public Secondary Schools in Kenya. Advances in Social Sciences Research Journal, 4(1) 106-120.

How They Develop Students' Talent in Preparatory Schools in Addis Ababa Addis Ababa Practice; Addis Ababa Education Bureau.

Sitra, SE (2003). Why are the children out of school?: Factors Affecting Children's Education in Egypt. A Paper for the ERF 9th annual conference. Sussex Brighton BN1 9RE United Kingdom.

UNESCO (2011). Youth and Skills: Putting Education to work. EFA Monitoring Report. UNESCO.

UNICEF (2005). Defining Quality in Education. A paper presented by UNICEF at the meeting of The International Working Group on Education Florence, Italy June 2000: A publication of UNICEF Programme Division; UNICEF New York.

Wasal K. and Mohammad I. (2014). Role of Co-Curricular Activities in School Effectiveness. Middle-East Journal of Scientific Research 21 (11): 2169-2176, Sarhad University of Science and Information Technology,

Peshawar, Khyber Pakhtunkhwa, Pakistan ISSN 1990-923. IDOSI Publications. 